\title{
Smoking Initiation, Tobacco Product Use, and Secondhand Smoke Exposure Among General Population and Sexual Minority Youth, Missouri, 2011-2012
}

\author{
Jenna N. Jordan, MPH; Jane A. McElroy, PhD; Kevin D. Everett, PhD \\ Suggested citation for this article: Jordan JN, McElroy JA, Everett KD. Smoking Initiation, Tobacco Product Use, and \\ Secondhand Smoke Exposure Among General Population and Sexual Minority Youth, Missouri, 2011-2012. Prev Chronic Dis \\ 2014;11:140037. DOI: http://dx.doi.org/10.5888/pcd11.140037 圆.
}

PEER REVIEWED

\section{Abstract}

\section{Introduction}

Research indicates disparities in risky health behaviors between heterosexual and sexual minority (referred to as LGBQ; also known as lesbian, gay, bisexual, queer, and questioning) youth. Limited data are available for tobacco-use-related behaviors beyond smoking status. We compared data on tobacco age of initiation, product use, and secondhand smoke exposure between general population and LGBQ youth.

\section{Methods}

Data for general population youth were from the statewide, representative 2011 Missouri Youth Tobacco Survey, and data for LGBQ youth were from the 2012 Out, Proud and Healthy survey (collected at Missouri Pride Festivals). Age-adjusted Cochran-Mantel-Haenszel tests were used to examine differences between general population $(\mathrm{N}=1,547)$ and LGBQ $(\mathrm{N}=$ 410) youth, aged 14 to 18 years. Logistic regression models identified variables associated with current smoking.

\section{Results}

The 2 groups differed significantly on many tobacco-use-related factors. General population youth initiated smoking at a younger age, and LGBQ youth did not catch up in smoking initiation until age 15 or 16. LGBQ youth (41.0\%) soon surpassed general population youth (11.2\%) in initiation and proportion of current smokers. LGBQ youth were more likely to use cigars/cigarillos, be poly-tobacco users, and be exposed to secondhand smoke (SHS) in a vehicle (for never smokers). Older age (odds ratio $[\mathrm{OR}]=1.39,95 \%$ confidence interval $[95 \% \mathrm{CI}]=1.18-1.62)$, female $\operatorname{sex}(\mathrm{OR}=1.64,95 \% \mathrm{CI}=1.13-2.37)$, LGBQ identity $(\mathrm{OR}=3.86,95 \% \mathrm{CI}=2.50-5.94)$, other tobacco product use $(\mathrm{OR}=8.67,95 \% \mathrm{CI}=6.01-12.51)$, and SHS exposure in a vehicle $\left(\mathrm{OR}=5.97,95 \% \mathrm{CI}=3.83^{-9.31}\right)$ all significantly increased the odds of being a current smoker.

\section{Conclusion}

This study highlights a need for the collection of data on sexual orientation on youth tobacco surveys to address health disparities among LGBQ youth.

\section{Introduction}

A growing body of research shows a higher proportion of smoking among sexual minority (referred to as LGBQ; also known as lesbian, gay, bisexual, queer, and questioning) than among heterosexual youth (1-5), and this disparity persists in adulthood (6-8). These disparities exist regardless of whether LGBQ status is defined by identity, attraction, or sexual behavior (6). Similarly, differences in age of smoking initiation were found between LGBQ and heterosexual youth in a longitudinal cohort study of adolescents, though data are sparse (1). Other sources of nicotine used by youth include chew, snus, cigars, and cigarillos. Research on a representative sample of US high school youth examined the concurrent use of multiple tobacco products; data indicated the prevalence of poly-tobacco use to be $21.7 \%$ among sexual minority youth compared with only $12.1 \%$ among heterosexual youth (9).

During the past 2 decades, exposure to secondhand smoke (SHS) has been linked to adverse health outcomes in both adults and children (10). Current research that is nationally representative of US youth has demonstrated that approximately $40 \%$ of middle- and high-school-age students are exposed to SHS in the home (11). Less is known about youth SHS exposure in vehicles; for example, a study using the nationally representative National Youth Tobacco Survey reported that one-fifth of 
nonsmoking youth are exposed to SHS in cars (12). No data on SHS exposure in the home or vehicle by LGBQ status were identified.

Because studies of risky behaviors and tobacco use among youth often collect data on a range of social and health issues, the information on tobacco use is limited and rarely includes measures of poly-tobacco use, SHS exposure, or support for smoke-free policies. The objective of this study was to 1) compare use of tobacco products, poly-tobacco use, and SHS exposure between Missouri general population and LGBQ youth; and 2) explore the relationship between smoking initiation, age, and LGBQ status among Missouri youth.

\section{Methods}

The Missouri Youth Tobacco Survey (MYTS) has been conducted by the Missouri Department of Health and Senior Services with the Centers for Disease Control and Prevention (CDC) every other year since 2003. A cluster probability sampling plan was used and included all regular and charter public schools in Missouri. Schools were randomly selected to participate on the basis of a probability proportional to the school enrollment size. In the second stage of random sampling, classrooms in these schools were randomly selected. The overall participation proportion for survey completion was $72.1 \%$ (13).

Attendees at 6 Pride Festivals in Missouri (Kansas City, Columbia, Springfield, Joplin, St. Louis, and Black Pride St. Louis) during the summer of 2012 were asked to complete an anonymous 28-item paper survey known as the Out, Proud and Healthy (OPAH) survey. The Behavioral Risk Factor Surveillance System survey (14) was used as a guide for developing questions about tobacco use histories and SHS exposure. Basic demographic information was also collected. Compensation was not provided, but participants were offered bubbles, stickers, and ice water. The survey took approximately 10 minutes to complete. The eligibility criterion was being able to read English. The University of Missouri Health Sciences institutional review board approved the study for participants of all ages.

The MYTS did not collect data on sexual orientation. Individuals in the OPAH study were classified as sexual minorities on the basis of their response to the question "Do you consider yourself to be (lesbian, gay, bisexual, straight/heterosexual, other/please specify, or don't know/not sure).” LGBQ status was defined as giving a response other than "straight/heterosexual." The MYTS and OPAH surveys differed somewhat on their operationalization of tobacco-related variables, though the measures were comparable (Appendix).

Descriptive statistics and Cochran-Mantel-Haenszel tests were used to examine age-adjusted differences between the general population and LGBQ respondents on variables related to smoking initiation, tobacco product use, and SHS exposure. Only data on high school-aged youth (aged 14-18 years) were analyzed. Logistic regression models identified variables associated with current smoking. Additional regression analyses were conducted to identify variables associated with current smoking for youth aged 14 to 17 years and aged 18 years. Analyses were conducted using SAS 9.3 statistical software (SAS Institute, Inc, Cary, North Carolina).

\section{Results}

Of the 5,243 OPAH surveys collected, participants who were missing data on age or LGBQ status $(\mathrm{N}=228)$, aged 13 years or younger $(\mathrm{N}=24)$, aged 19 years or older $(\mathrm{N}=4,389)$, heterosexual youth $(\mathrm{N}=166)$, youth completing the survey online ( $\mathrm{N}$ $=5)$, and youth identifying as transgender or transsexual $(\mathrm{N}=21)$ were excluded from analyses, bringing the final data set of LGBQ youth to 410 participants. The LGBQ sample included 113 lesbian (28\%), 96 gay (23\%), 143 bisexual (35\%), and 58 other LGBQ/don't know/not sure (14\%) youth. The LGBQ and general population youth had a similar racial composition; most identified as white (LGBQ, 76.6\%; general population, 79.5\%). The 2 groups differed significantly by age (LGBQ mean age, 16.9 years; general population age, 16.2 years), Hispanic ethnicity (LGBQ, 6.7\%; general population, 2.3\%), and sex (LGBQ, 30.5\% male; general population, 54.5\% male) (Table 1).

No differences in the proportion of current smokers were found by sex in LGBQ youth (male participants, 38.8\%; female participants, $42.2 \%$ ) or general population youth (male participants, $11.9 \%$; female participants, 10.5\%). The groups differed significantly, however, on many smoking status variables (Table 1). Overall, LGBQ youth were significantly more likely to have smoked at least 100 cigarettes in their lives. However, when examined by age, general population youth aged 14 to 17 were more likely than their LGBQ counterparts to have smoked at least 100 cigarettes. The percentage of youth initiating smoking at each age showed a similar pattern for LGBQ and general population youth, with a slight delay in initiation for LGBQ youth (Figure 1). At age 14, the percentage of current smokers was similar for the 2 groups (LGBQ, o.8\%; general population, $2.5 \%$ ). For ages 15, 16, and 17, the percentage of current smokers was higher among the general population youth. Then at age 18, the percentage of current smokers among LGBQ youth (47.7\%) nearly doubled that of youth from the general population (24.2\%) (Figure 2). The overall LGBQ sample had a 41.0\% current smoking prevalence compared with $\mathbf{1 1 . 2 \%}$ in the general population, and, among smokers, LGBQ youth had a higher prevalence of daily smoking (LGBQ, $52.6 \%$; general population, $33.7 \%$ ). 


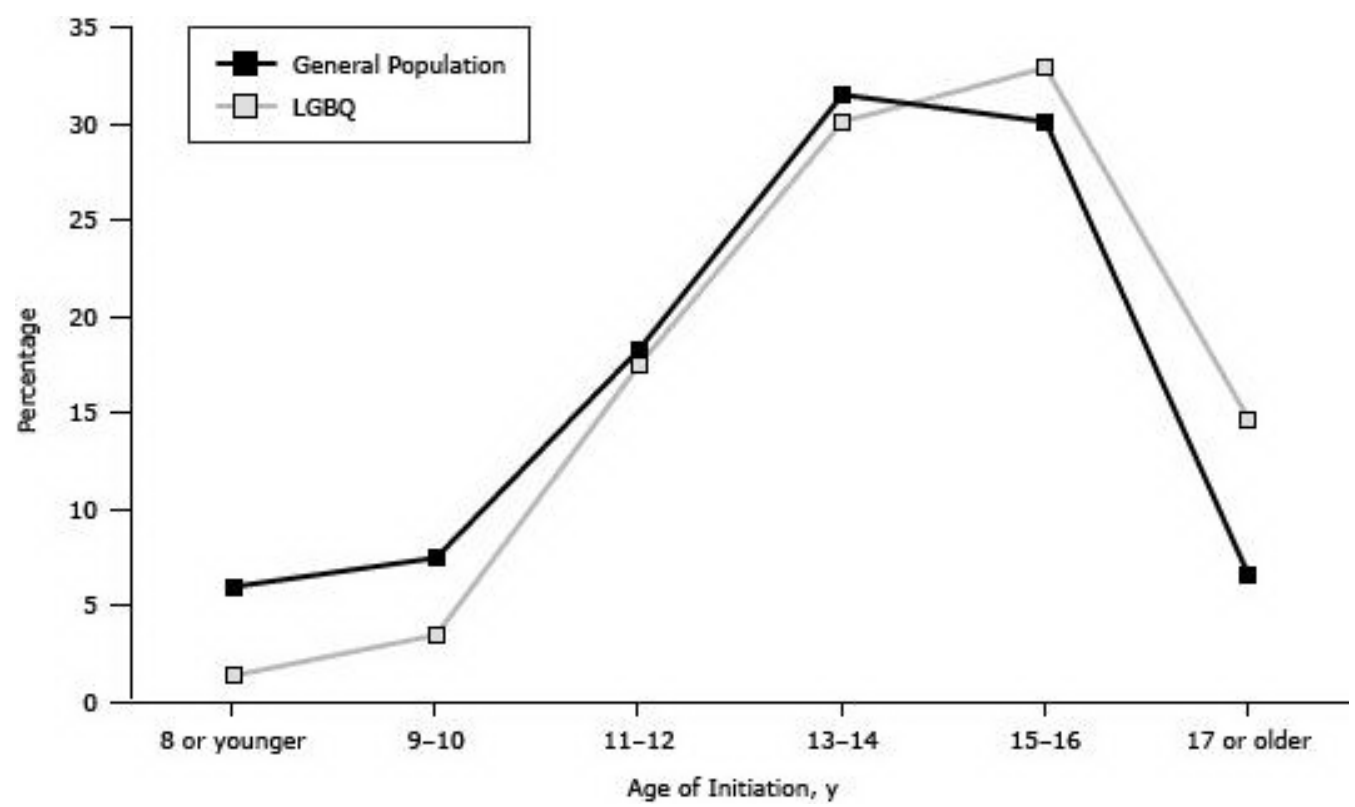

Figure 1. Age of smoking initiation (current smokers only) among LGBQ and general population youth, Missouri Youth Tobacco Survey and Out, Proud and Healthy Survey, Missouri, 2011-2012. Abbreviation: LGBQ, lesbian, gay, bisexual, queer and questioning. [A tabular version of this figure is also available.]

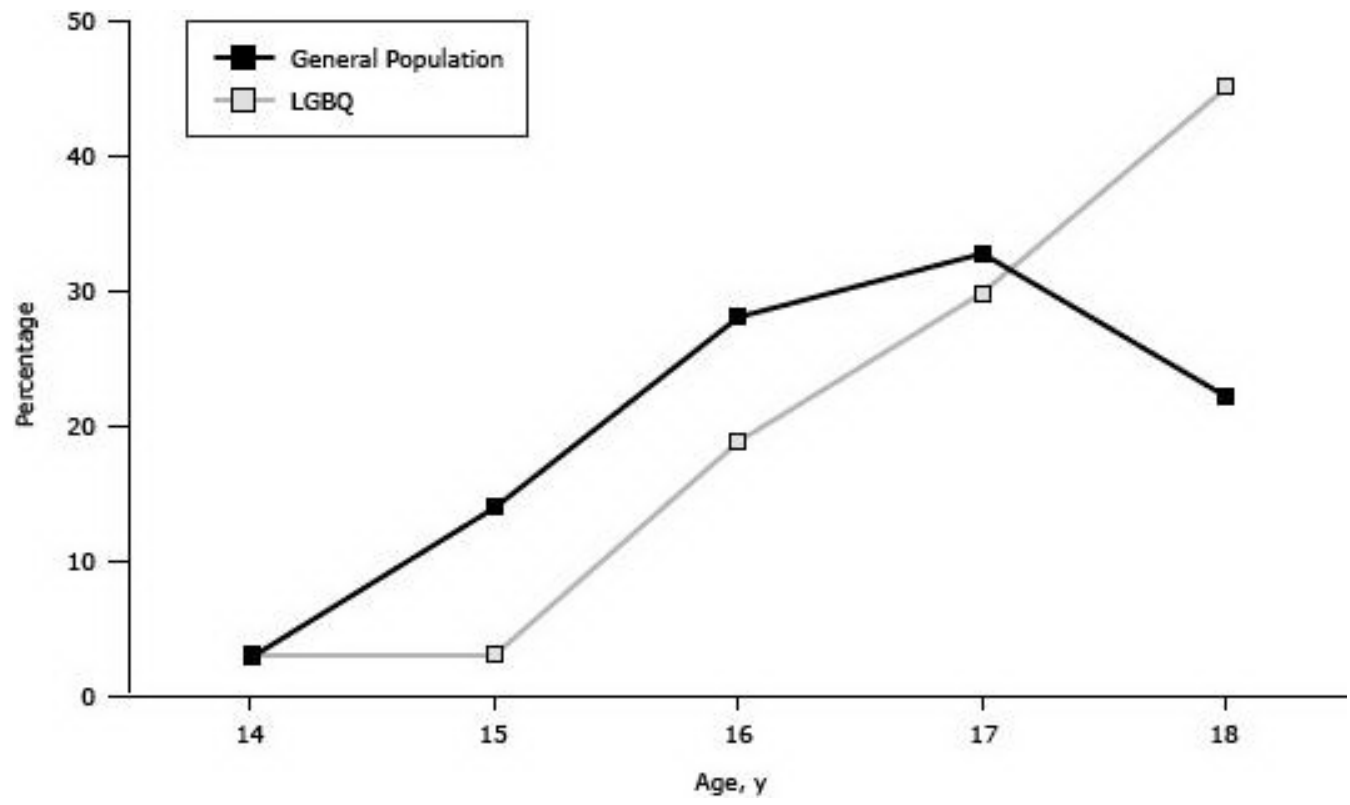

Figure 2. Percentage of current smokers, by age, among LGBQ and general population youth, Missouri Youth Tobacco Survey and Out, Proud and Healthy Survey, Missouri, 2011-2012. Abbreviation: LGBQ, lesbian, gay, bisexual, queer and questioning. [A tabular version of this figure is also available.]

In addition, LGBQ youth were significantly more likely than general population youth to smoke cigarettes (male and female participants), to smoke cigars/cigarillos (male and female participants), be poly-tobacco users (male and female participants (Table 1, Figure 3), be exposed to SHS in a vehicle (never smokers), and to report not supporting smoke-free indoor workplaces. Conversely, general population youth were significantly more likely to initiate smoking younger, use chewing tobacco (male participants), and be exposed to SHS in the home (never and current smokers). When SHS exposure in a vehicle for current smokers was examined dichotomously (never allowed vs sometimes allowed/always allowed), LGBQ and general population youth did not significantly differ. 


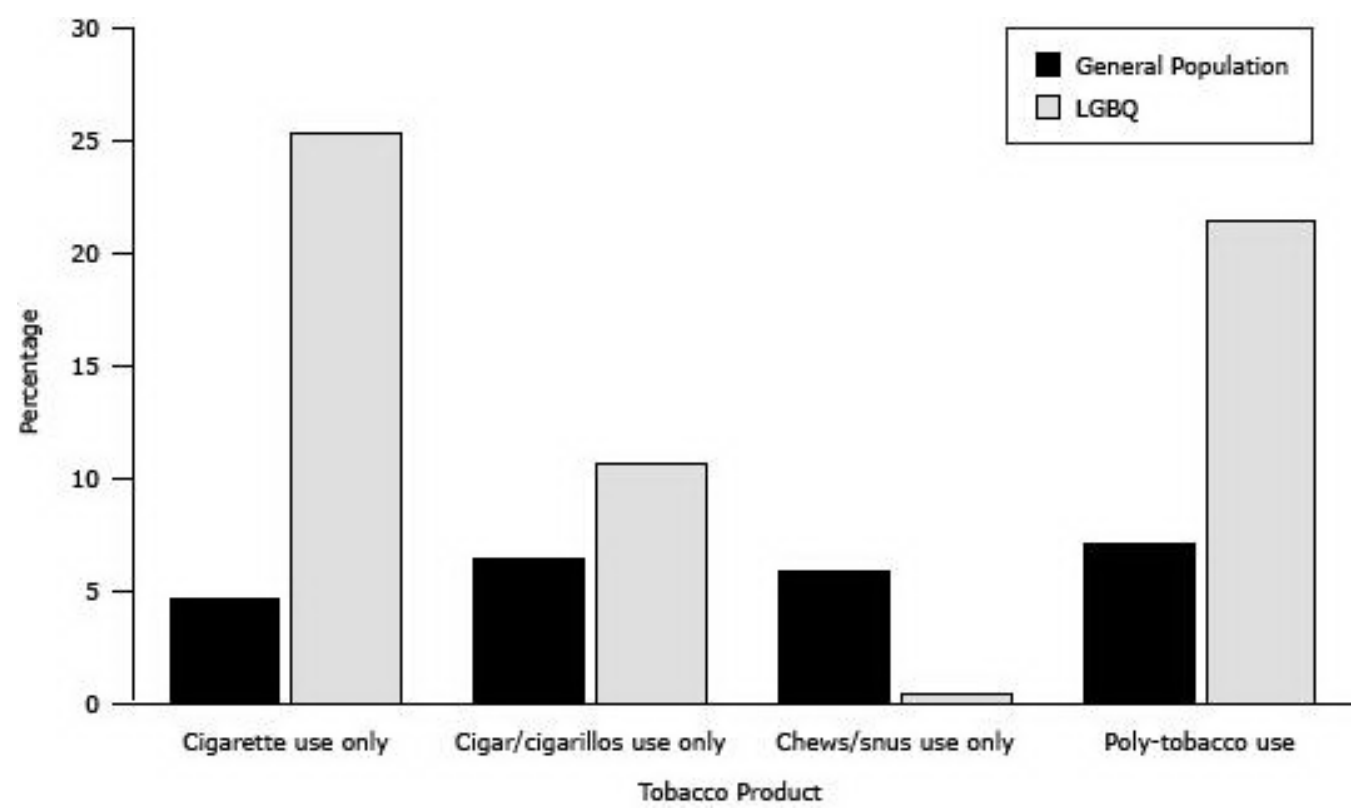

Figure 3. Types of Tobacco Use Among LGBQ and General Population Youth, Missouri Youth Tobacco Survey and Out, Proud and Healthy Survey, 2011-2012. Abbreviation: LGBQ, lesbian, gay, bisexual, queer and questioning. [A tabular version of this figure is also available.]

Logistic regression analysis identified variables associated with current smoking. Age (OR = 1.39, 95\% CI = 1.18-1.62), female sex $(\mathrm{OR}=1.64,95 \% \mathrm{CI}=1.13-2.37)$, LGBQ identity $(\mathrm{OR}=3.86,95 \% \mathrm{CI}=2.50-5.94)$, using a tobacco product other than cigarettes $(\mathrm{OR}=8.67,95 \% \mathrm{CI}=6.01-12.51)$, and allowing smoking in the vehicle $(\mathrm{OR}=5.97,95 \% \mathrm{CI}=3.83-9.31)$ all significantly increased the odds of being a current smoker. Conversely, black race $(\mathrm{OR}=0.47,95 \% \mathrm{CI}=0.26-0.84)$ and supporting smoke-free indoor workplace policies $(0.48,95 \% \mathrm{CI}=0.34-0.69)$ were protective against current smoking (Table 2). For 14- to 17-year-olds, the variables associated with current smoking remained the same as in the original model. However, for 18-year-olds, female sex was no longer significant in the model.

\section{Discussion}

This study found LGBQ youth to be at an increased risk for smoking at least 100 lifetime cigarettes, current smoking, daily smoking, poly-tobacco use, cigar/cigarillo smoking, and exposure to SHS in a vehicle (for never smokers) compared with general population youth. However, the general population youth initiated smoking at a younger age, were more likely to use chew tobacco/snus (for male participants), and be exposed to SHS in the home. Consistent with findings from previous studies on smoking rates, our findings indicate that significantly more LGBQ youth than heterosexual youth are smoking by age 18. Our study extended findings on tobacco-use-related behaviors and exposures by showing a significant disparity in poly-tobacco use, other tobacco product use, and private-space SHS exposure for LGBQ youth compared with their general population counterparts.

The concurrent use of multiple tobacco products is a public health concern, because it could lead to greater nicotine dependence, which is especially true for youth who may be experimenting with various tobacco products and increasing their nicotine exposure (9). Approximately 2.5 times more LGBQ male youth and 5 times more LGBQ female youth were poly-tobacco users compared with their general population counterparts. Excluding current cigarette smokers, LGBQ youth were more likely to smoke cigars/cigarillos, and general population youth were more likely to use chew/snus. As a result, the much higher proportion of poly-tobacco use seen in the LGBQ sample is driven by the high proportion of cigarette smoking. However, youth who use more than 1 tobacco product are more likely to engage in health risk behaviors that are linked to substantial rates of morbidity and mortality in youth (15), suggesting LGBQ youth are at increased risk for illness and death.

The differences in tobacco use by LGBQ status may be the result of the socially based stressors that LGBQ youth face such as stigma, discrimination, and a lack of acceptance from friends and family. In the stress and coping model of adolescent substance abuse, people who experience high levels of stress and a lack of healthy coping resources (ie, social support) may use tobacco products in an attempt to cope with stress (16). A study by Rosario and colleagues followed a group of LGB youth longitudinally for 1 year to determine whether the heightened risk of cigarette smoking in this population resulted from the belief among LGB youth that smoking would serve as a coping strategy for the greater stress they experienced as a result of their sexual orientation (17). The results showed that smoking increased the negative association between stressors and psychological distress, although both friend and family support buffered this association (17). Despite perceptions among youth that smoking is an effective coping strategy for stress, smoking may have adverse consequences for distress (17), thus perpetuating the high smoking rates seen in this population. 
LGBQ youth also experience high levels of rejection and less support from their parents and peers (18), which may contribute to the higher prevalence of tobacco use in this population. One convenience sample study found that parental rejection behaviors toward adolescent sexual orientation predicted negative health problems such as illegal drug use in young adulthood (19). In addition, at-school victimization has been shown to negatively influence LGBQ youths' health risk behaviors (20) and increase suicidality (21).

Relationships among different facets of life are an important factor in tobacco use (22). Primary socialization theory emphasizes the relationships between individuals and their family, peers, and school faculty as the conduit through which information about norms and behaviors is conveyed (22). According to this theory, when the bonds between adolescents and others is strong and the influence is prosocial, youth are not as likely to engage in tobacco use; however, when these bonds are weak, the influence of peers increases along with the likelihood that these peers will be composed of youth who promote substance use behaviors (22). In this case, when nonsmoking youth are friends with smokers and have weak relationships with family and school faculty, they are more likely to become smokers themselves than are youth who do not associate with smokers (23). Although these theories have been applied to general population youth, they likely extend to LGBQ youth, who are also influenced by relationships with family, peers, and school faculty.

The lower proportion of LGBQ youth smoking before the age of 18 compared with general population youth may be explained by an instability of identity or self-concept (24), which does not stabilize until late adolescence (25). In this sense, identifying as LGBQ at a young age may create a sense of isolation that prevents these youth from learning smoking behaviors from peer groups. Ages 18 to 19 may be a time by which self-concept is established (26), when many LGBQ individuals disclose their sexual orientation ("come out"), leave their family home, and begin socializing with other LGBQ individuals and groups; as a result, they may begin smoking as a way of forging connections with new friends. In large part, youth view themselves in terms of their surrounding contexts when it comes to self-definition (27), and, by viewing LGBQ individuals as their peers, LGBQ youth may be modeling their tobacco use behaviors after a group that has been consistently shown to have a high prevalence (up to 50\%) of tobacco use (7).

For LGBQ youth, tobacco product (single and combined) use and SHS exposure in cars for never smokers place this population at increased risk for tobacco-related illness (28). Despite fewer LGBQ youth being exposed to smoking in the home, a higher proportion of LGBQ youth smoke compared with general population youth, indicating that rules about smoking in the vehicle are more predictive of current smoking than rules about smoking in the home. This conclusion is also supported by the results of the regression analysis, which found that allowing smoking in the vehicle increased the odds of current smoking by 6 times, while allowing smoking in the home was not significant in the model. These findings also highlight the importance of peer influences on smoking. Although youth may have no control over the rules about smoking in their home, they may be able to determine rules about smoking in their own vehicles or friends' vehicles where parental rules cannot always be enforced.

This study has several limitations. The operationalization of our OPAH tobacco-related measures sometimes differed from those of the MYTS, though both measure the same concepts. In addition, the MYTS reported findings for the general population, which would have included some LGBQ participants, introducing misclassification error. The small percentage of general population youth self-identifying as LGBQ is unlikely to substantially change our results, as LGBQ youth are at a higher risk for many tobacco-use and SHS variables, and, if any effect was seen, it would be a slight increase in general population risk. Despite this, the differences seen in tobacco and SHS variables remain significant between the groups. Finally, although this study has a large sample size of more than 400 self-identified LGBQ youth, the participants are a nonprobabilistic sample of participants, and the findings may not extend to all LGBQ Missouri youth.

The lack of nationally representative data on tobacco use in LGBQ youth results in few effective, evidence-based prevention, cessation, and counter-marketing campaigns for this group. In 2012, the American Legacy Foundation found that the only national data available on tobacco use and sexual orientation were from the National Adult Tobacco Survey, which omits youth (29). During 2011, only 21 sites (encompassing states, large school districts, territories, and tribal governments) in the United States asked students' sexual identity and the sex of students' sexual contacts on the Youth Risk Behavior Survey (YRBS) (30). The CDC encourages YRBS sites to add questions about same-sex sexual contact and sexual identity to their surveys to better understand the health risks among LGBQ youth and to develop appropriate prevention strategies (30). This study provides evidence for the inclusion of sexual orientation on youth tobacco and health surveys to address these disparities.

Future studies should further explore the reasons for delayed smoking initiation in LGBQ youth, and interventions should target LGBQ youth at a young age. Interventions that may be most effective for LGBQ youth are those that address the hazards of using tobacco products other than cigarettes (ie, cigars/cigarillos) and poly-tobacco use, as well as those that break the association between identifying as a member of the LGBQ community and smoking. It may also be beneficial to address issues unique to LGBQ females who often use tobacco products at equal or higher rates than LGBQ males. These interventions should include former smokers or nonsmokers from the LGBQ community and provide opportunities for LGBQ youth to socialize in smoke-free venues. At the individual level, LGBQ youth need to be provided with positive and healthy coping mechanisms to address the discrimination and stress they may experience. At the societal level, tobacco and SHS exposure disparities in the LGBQ community need to be treated as social justice and policy issues arising from widespread discrimination, victimization, and health care inequalities. Without identifying LGBQ status on health surveys and studies, health educators and practitioners cannot monitor trends in LGBQ youth tobacco product use, engage with this 
at-risk population, address the lack of LGBQ representation in mainstream tobacco control, or develop tailored prevention and cessation programs to reduce tobacco use in this population.

\section{Acknowledgments}

Data for this publication were obtained in part from the MYTS conducted under the direction of the Missouri Department of Health and Senior Services (MDHSS). Funding for the MYTS was provided by Missouri Tobacco Control Program through a cooperative agreement with the CDC Office on Smoking and Health. The interpretation and conclusions of the data are the sole responsibility of the author and not that of the MDHSS or CDC. Support for the Out, Proud and Healthy project was provided by the Missouri Foundation for Health (11-0439-TRD-11).

\section{Author Information}

Corresponding Author: Jenna N. Jordan, MA, 306 Medical Sciences Bldg, University of Missouri, Columbia, MO 65212. Telephone: 573-884-0o89. E-mail: jnjxv8@mail.missouri.edu.

Author Affiliations: Jane A. McElroy, Kevin D. Everett, University of Missouri, Department of Family and Community Medicine, Columbia, Missouri.

\section{References}

1. Corliss HL, Wadler BM, Jun HJ, Rosario M, Wypij D, Frazier AL, et al. Sexual-orientation disparities in cigarette smoking in a longitudinal cohort study of adolescents. Nicotine Tob Res 2013;15(1):213-22. CrossRef 国 PubMed 圈

2. Austin SB, Ziyadeh N, Fisher LB, Kahn JA, Colditz GA, Frazier AL. Sexual orientation and tobacco use in a cohort study of US adolescent girls and boys. Arch Pediatr Adolesc Med 2004;158(4):317-22. CrossRef 圈 PubMed 圈

3. Easton A, Jackson K, Mowery P, Comeau D, Sell R. Adolescent same-sex and both-sex romantic attractions and relationships: implications for smoking. Am J Public Health 2008;98(3):462-7. CrossRef 国 PubMed 圈

4. Brewster KL, Tillman KH. Sexual orientation and substance use among adolescents and young adults. Am J Public Health 2012;102(6):1168-76. CrossRef 圈 PubMed 圈

5. Ryan H, Wortley PM, Easton A, Pederson L, Greenwood G. Smoking among lesbians, gays, and bisexuals: a review of the literature. Am J Prev Med 2001;21(2):142-9. CrossRef 圈 PubMed 国

6. Lee JG, Griffin GK, Melvin CL. Tobacco use among sexual minorities in the USA, 1987 to May 2007: a systematic review. Tob Control 2009;18(4):275-82. CrossRef 国 PubMed 圈

7. McElroy JA, Everett KD, Zaniletti I. An examination of smoking behavior and opinions about smoke-free environments in a large sample of sexual and gender minority community members. Nicotine Tob Res 2011;13(6):440 -8. CrossRef 国 PubMed 国

8. Rath JM, Villanti AC, Rubenstein RA, Vallone DM. Tobacco use by sexual identity among young adults in the United States. Nicotine Tob Res 2013; Online First.

9. Rosario M, Corliss HL, Everett B, Reisner SL, Austin SB, Buchting FO, et al. Sexual orientation disparities in cancerrelated risk behaviors of tobacco, alcohol, sexual behaviors, and diet and physical activity: pooled youth risk behavior surveys. Am J Public Health 2014;104(2):245-54. CrossRef 圆 PubMed 圈

10. Sureda X, Fernandez E, Lopez MJ, Nebot M. Secondhand tobacco smoke exposure in open and semi-open settings: a systematic review. Environ Health Perspect 2013;121(7):766-73. CrossRef 国 PubMed 国

11. Agaku IT, Vardavas CI. Disparities and trends in indoor exposure to secondhand smoke among US adolescents: 200o2009. PLoS ONE 2013;8(12):e83058. CrossRef 国 PubMed 圈

12. King BA, Dube SR, Tynan MA. Secondhand smoke exposure in cars among middle and high school students - United States, 2000-2009. Pediatrics 2012;129(3):446-52. CrossRef 国 PubMed 国

13. Results from the 2011 Missouri Youth Tobacco Survey. Missouri Department of Health and Senior Services, Office of Epidemiology; 2011.

http://health.mo.gov/living/wellness/tobacco/smokingandtobacco/pdf/2011YouthTobaccoSurvey.pdf. Updated December 2011. Accessed August 22, 2013.

14. Behavioral risk factor surveillance system survey questionnaire. US Department of Health and Human Services, Centers for Disease Control and Prevention; 2008. http://www.cdc.gov/brfss/questionnaires/pdf-ques/2008brfss.pdf. Updated December 31, 2007. Accessed August 6, 2013.

15. Everett SA, Malarcher AM, Sharp DJ, Husten CG, Giovino GA. Relationship between cigarette, smokeless tobacco, and cigar use, and other health risk behaviors among US high school students. J Sch Health 2000;70(6):234-40. CrossRef 四 PubMed 睞

16. Wills TA, Filer M. Stress-coping model of adolescent substance use. In: Ollendick TH, Prinz RJ, editors. Advances in clinical child psychology, vol. 18. New York (NY): Plenum Press; 1996. p. 91-132. 
Preventing Chronic Disease | Smoking Initiation, Tobacco Product Use, and Secondhand ... Page 7 of 12

17. Rosario M, Schrimshaw EW, Hunter J. Cigarette smoking as a coping strategy: negative implications for subsequent psychological distress among lesbian, gay and bisexual youths. J Pediatr Psychol 2011;36(7):731-731742. CrossRef 圈 PubMed恩

18. Williams T, Connolly J, Pepler D, Craig W. Peer victimization, social support, and psychosocial adjustment of sexual minority adolescents. J Youth Adolesc 2005;34(5):471-82. CrossRef 圈

19. Ryan C, Hueber D, Diaz RM, Sanchez J. Family rejection as a predictor of negative health outcomes in white and Latino lesbian, gay, and bisexual young adults. Pediatrics 2009;123(1):346-52. CrossRef 圈 PubMed 圈

20. Bontempo DE, D'Augelli AR. Effects of at-school victimization and sexual orientation on lesbian, gay, or bisexual youths' health risk behavior. J Adolesc Health 2002;30(5):364-74. CrossRef 因 PubMed 圈

21. Russell ST, Joyner K. Adolescent sexual orientation and suicide risk: evidence from a national study. Am J Public Health 2001;91(8):1276-81. CrossRef 圈 PubMed 圈

22. Oetting ER, Deffenbacher JL, Donnermeyer JF. Primary socialization theory. The role played by personal traits in the etiology of drug use and deviance. II. Subst Use Misuse 1998;33(6):1337-66. CrossRef 圈 PubMed 圆

23. Urberg KA, Degirmencioglu SM, Pilgrim C. Close friend and group influence on adolescent cigarette smoking and alcohol use. Dev Psychol 1997;33(5):834-44. CrossRef 圈 PubMed 圈

24. Rosenberg M. Self-concept and psychological well-being in adolescence. In: Leahy RL, editor. The development of the self. Orlando (FL): Academic Press; 1985. p. 205-46.

25. Boardman JD. Self-rated health among US adolescents. J Adolesc Health 2006;38(4):401-8. CrossRef 圈 PubMed 圈

26. Stryker S. Symbolic interactionism: a social structural version. Menlo Park (CA): Benjamin/Cummings; 1980.

27. Damon W, Hart D. Self-understanding in childhood and adolescence. New York (NY): Cambridge University Press; 1988.

28. Child and teen tobacco use. American Cancer Society; 2012.

http://www.cancer.org/acs/groups/cid/documents/webcontent/o02963-pdf.pdf. Updated November 8, 2012.

Accessed August 21, 2013.

29. Tobacco fact sheet: lesbian, gay, bisexual, and transgender (LGBT) communities and smoking. Washington (DC):

American Legacy Foundation; 2012.

http://www.legacyforhealth.org/content/download/593/7117/file/LGBT_Communities_and_Smoking_2012.pdf.pdf. Updated November 2012. Accessed August 19, 2013.

30. LGBTQ youth programs-at-a-glance. Centers for Disease Control and Prevention; 2013. http://www.cdc.gov/lgbthealth/youth-programs.htm. Updated May 16, 2013. Accessed August 21, 2013.

\section{Tables}

Table 1. Cochran-Mantel-Haenszel Age-Controlled Comparisons of LGBQ and Missouri Youth on Demographics, Tobacco Use, Secondhand Smoke Exposure, and Attitudes About Smoking, Missouri Youth Tobacco Survey and Out, Proud and Healthy Survey, Missouri, 2011-2012a

\begin{tabular}{|l|r|r|}
\hline Characteristic/Behavior/Attitude & LGBQ (N = 410) & General Population (N = 1,547) \\
\hline Mean age, y (standard deviation)b & $16.9(1.1)$ & $16.2(1.1)$ \\
\hline Sexc & \multicolumn{3}{|r|}{} \\
\hline Maleb & 30.5 & 54.5 \\
\hline Femaleb & 69.5 & 45.5 \\
\hline Racec & 19.0 & 16.7 \\
\hline Black & 1.1 & 1.6 \\
\hline Asian & 76.6 & 79.5 \\
\hline White & 3.4 & 1.6 \\
\hline American Indian & 0 & 0.6 \\
\hline Native Hawaiian & \multicolumn{3}{|r|}{} \\
\hline Ethnicityc & 6.7 & 2.3 \\
\hline Hispanic & \multicolumn{3}{|r|}{} \\
\hline
\end{tabular}




\begin{tabular}{|c|c|c|}
\hline Characteristic/Behavior/Attitude & LGBQ $(N=410)$ & General Population $(N=1,547)$ \\
\hline \multicolumn{3}{|c|}{ Have you smoked at least 100 cigarettes?c } \\
\hline Yesb & 31.8 & 12.8 \\
\hline \multicolumn{3}{|l|}{ Smoking statusc } \\
\hline Neverb & 55.5 & 87.3 \\
\hline Former & 3.5 & 1.6 \\
\hline Currentb & 41.0 & 11.2 \\
\hline \multicolumn{3}{|l|}{ Current smoker at age, $y$} \\
\hline 14 & 0.8 & 2.5 \\
\hline 15 & 3.1 & 13.6 \\
\hline $16 \mathrm{~b}$ & 19.5 & 29.3 \\
\hline $17 \mathrm{~b}$ & 28.9 & 30.3 \\
\hline $18 \mathrm{~b}$ & 47.7 & 24.2 \\
\hline \multicolumn{3}{|l|}{ Current smokerc } \\
\hline Every dayb & 52.6 & 33.7 \\
\hline Some daysd & 47.4 & 66.3 \\
\hline \multicolumn{3}{|c|}{ Age of smoking initiation (current smokers), yc } \\
\hline 8 or younger & 1.4 & 6.0 \\
\hline 9 or 10 & 3.5 & 7.5 \\
\hline 11 or 12 & 17.5 & 18.3 \\
\hline 13 or 14 & 30.1 & 31.5 \\
\hline 15 or 16 & 32.9 & 30.1 \\
\hline 17 or olderd & 14.7 & 6.6 \\
\hline \multicolumn{3}{|c|}{ On the days you smoke, how many cigarettes do you smoke (current smokers)?c } \\
\hline 5 or fewer & 56.1 & 55.0 \\
\hline $6-10$ & 23.8 & 29.2 \\
\hline $11-20$ & 14.0 & 10.5 \\
\hline$\geq 21$ & 6.1 & 5.3 \\
\hline \multicolumn{3}{|c|}{ Do you currently use chewing tobacco, snuff, or snus (male respondents only)?c } \\
\hline Not at alld & 94.3 & 82.1 \\
\hline Every dayb & 0 & 7.3 \\
\hline Some days & 5.7 & 10.6 \\
\hline \multicolumn{3}{|c|}{ Do you currently use chewing tobacco, snuff, or snus (female respondents only)?c } \\
\hline Not at alld & 97.8 & 98.0 \\
\hline Every dayd & 1.1 & 0.4 \\
\hline Some days & 1.1 & 1.6 \\
\hline \multicolumn{3}{|c|}{ Do you currently smoke cigars or cigarillos (male respondents only)?c } \\
\hline Not at all & 73.1 & 82.9 \\
\hline Every day & 1.7 & 2.0 \\
\hline Some days & 25.2 & 15.1 \\
\hline \multicolumn{3}{|c|}{ Do you currently smoke cigars or cigarillos (female respondents only)?c } \\
\hline Not at allb & 70.4 & 92.0 \\
\hline
\end{tabular}




\begin{tabular}{|c|c|c|}
\hline Characteristic/Behavior/Attitude & LGBQ $(N=410)$ & General Population ( $N=1,547)$ \\
\hline Every dayb & 2.2 & 0.1 \\
\hline Some daysb & 27.4 & 7.8 \\
\hline \multicolumn{3}{|c|}{ Poly-tobacco use (male respondents only)?c } \\
\hline Yesb & 25.8 & 9.4 \\
\hline \multicolumn{3}{|c|}{ Poly-tobacco use (female respondents only)?c } \\
\hline Yesb & 19.8 & 4.4 \\
\hline \multicolumn{3}{|c|}{ Support for smoke-free indoor workplace policiesc } \\
\hline Yesb & 54.0 & 75.3 \\
\hline \multicolumn{3}{|c|}{ Which statement best describes the rules about smoking when you travel (never smokers)? Smoking is ....c } \\
\hline Not allowed in any vehicle I travel inb & 46.5 & 68.0 \\
\hline Allowed sometimesb & 32.4 & 16.7 \\
\hline Always allowed & 21.1 & 15.2 \\
\hline \multicolumn{3}{|c|}{ Which statement best describes the rules about smoking when you travel (current smokers)? Smoking is ... .c } \\
\hline Not allowed in any vehicle I travel in & 9.8 & 14.2 \\
\hline Allowed sometimesd & 49.6 & 25.4 \\
\hline Always allowedb & 40.7 & 60.4 \\
\hline \multicolumn{3}{|c|}{ Which statement best describes the rules about smoking inside your home (never smokers)? Smoking is ... .c } \\
\hline Not allowedb & 77.7 & 74.0 \\
\hline Sometimes allowed & 10.8 & 11.5 \\
\hline Always allowed & 11.5 & 14.5 \\
\hline \multicolumn{3}{|c|}{ Which statement best describes the rules about smoking inside your home (current smokers)? Smoking is ....c } \\
\hline Not allowed & 76.3 & 41.1 \\
\hline Sometimes allowed & 16.1 & 19.6 \\
\hline Always allowedb & 7.6 & 39.3 \\
\hline
\end{tabular}

Abbreviation: LGBQ, lesbian, gay, bisexual, queer, and questioning.

a Values expressed as percentages, unless otherwise indicated. Percentages may not sum to $100 \%$ due to rounding.

b $P<.001$

c Variable controlled for age.

d $P<.01$.

Table 2. Logistic Regression Model for Characteristics, Behaviors, and Attitudes Associated With Current Smoking in Missouri Youth, Missouri Youth Tobacco Survey and Out, Proud and Healthy Survey, Missouri, 2011-2012

\begin{tabular}{|l|r|r|}
\hline Variable & $\begin{array}{r}\text { Odds Ratio (95\% Confidence } \\
\text { Interval) }\end{array}$ & $\begin{array}{c}\text { P } \\
\text { Value }\end{array}$ \\
\hline Older age (vs younger age) & $1.39(1.18-1.62)$ & $<.001$ \\
\hline Female sex (vs male sex) & $1.64(1.13-2.37)$ & .009 \\
\hline Black race (vs white race) & $0.47(0.26-0.84)$ & .01 \\
\hline LGBQ identity (vs general population) & $3.86(2.50-5.94)$ & $<.001$ \\
\hline Other tobacco use (vs no other tobacco use) & $8.67(6.01-12.51)$ & $<.001$ \\
\hline Support smoke-free indoor workplace policies (vs no support) & $0.48(0.34-0.69)$ & $<.001$ \\
\hline $\begin{array}{l}\text { Smoking allowed in the vehicle (vs smoking not allowed in the } \\
\text { vehicle) }\end{array}$ & $5.97(3.83-9.31)$ & $<.001$ \\
\hline
\end{tabular}




\section{Appendix. Differences in Measures of Missouri Youth Tobacco Survey and the Out, Proud and Healthy Survey, Missouri, 2011-2012}

\begin{tabular}{|c|c|c|}
\hline Variable & Missouri Youth Tobacco Survey & Out, Proud and Healthy Survey \\
\hline \multicolumn{3}{|c|}{ Smoking status } \\
\hline Never & $\begin{array}{l}\text { About how many cigarettes have you smoked in } \\
\text { your entire life? (response: none to } 99 \text { cigarettes) }\end{array}$ & $\begin{array}{l}\text { Have you smoked at least } 100 \text { cigarettes in your entire } \\
\text { life? (response: no) }\end{array}$ \\
\hline Former & $\begin{array}{l}\text { About how many cigarettes have you smoked in } \\
\text { your entire life? (response: } 100 \text { or more } \\
\text { cigarettes) } \\
\text { and } \\
\text { During the past } 30 \text { days, on how many days did } \\
\text { you smoke? (response: } 0 \text { days) }\end{array}$ & $\begin{array}{l}\text { Have you smoked at least } 100 \text { cigarettes in your entire } \\
\text { life? (response: yes) } \\
\text { and } \\
\text { Do you NOW smoke cigarettes every day, some days or } \\
\text { not at all? (response: not at all) }\end{array}$ \\
\hline Current & $\begin{array}{l}\text { About how many cigarettes have you smoked in } \\
\text { your entire life? (response: } 100 \text { or more } \\
\text { cigarettes) } \\
\text { and } \\
\text { During the past } 30 \text { days, on how many days did } \\
\text { you smoke? (response: } 1-30 \text { days) }\end{array}$ & $\begin{array}{l}\text { Have you smoked at least } 100 \text { cigarettes in your entire } \\
\text { life? (response: yes) } \\
\text { and } \\
\text { Do you NOW smoke cigarettes every day, some days or } \\
\text { not at all? (response: every day or some days) }\end{array}$ \\
\hline \multicolumn{3}{|c|}{ Current smoking } \\
\hline Not at all & $\begin{array}{l}\text { During the past } 30 \text { days, on how many did you } \\
\text { smoke? (response: } 0 \text { days) }\end{array}$ & $\begin{array}{l}\text { Do you NOW smoke cigarettes every day, some days or } \\
\text { not at all? (response: not at all) }\end{array}$ \\
\hline Some days & $\begin{array}{l}\text { During the past } 30 \text { days, on how many did you } \\
\text { smoke? (response: } 1-29 \text { days) }\end{array}$ & $\begin{array}{l}\text { Do you NOW smoke cigarettes every day, some days or } \\
\text { not at all? (response: some days) }\end{array}$ \\
\hline Every day & $\begin{array}{l}\text { During the past } 30 \text { days, on how many did you } \\
\text { smoke? (response: all } 30 \text { days) }\end{array}$ & $\begin{array}{l}\text { Do you NOW smoke cigarettes every day, some days or } \\
\text { not at all? (response: every day) }\end{array}$ \\
\hline \multicolumn{3}{|c|}{ Age of smoking initiation, $y$} \\
\hline $\begin{array}{l}8 \text { or } \\
\text { younger }\end{array}$ & $\begin{array}{l}\text { How old were you when you smoked a whole } \\
\text { cigarette for the first time? (response: } 8 \text { years or } \\
\text { younger) }\end{array}$ & $\begin{array}{l}\text { Age you started smoking? (response: } 8 \text { years or } \\
\text { younger) }\end{array}$ \\
\hline 9 or 10 & $\begin{array}{l}\text { How old were you when you smoked a whole } \\
\text { cigarette for the first time? (response: } 9 \text { or } 10 \\
\text { years old) }\end{array}$ & Age you started smoking? (response: 9 or 10 years old) \\
\hline 11 or 12 & $\begin{array}{l}\text { How old were you when you smoked a whole } \\
\text { cigarette for the first time? (response: } 11 \text { or } 12 \\
\text { years old) }\end{array}$ & $\begin{array}{l}\text { Age you started smoking? (response: } 11 \text { or } 12 \text { years } \\
\text { old) }\end{array}$ \\
\hline 13 or 14 & $\begin{array}{l}\text { How old were you when you smoked a whole } \\
\text { cigarette for the first time? (response: } 13 \text { or } 14 \\
\text { years old) }\end{array}$ & $\begin{array}{l}\text { Age you started smoking? (response: } 13 \text { or } 14 \text { years } \\
\text { old) }\end{array}$ \\
\hline 15 or 16 & $\begin{array}{l}\text { How old were you when you smoked a whole } \\
\text { cigarette for the first time? (response: } 15 \text { or } 16 \\
\text { years old) }\end{array}$ & $\begin{array}{l}\text { Age you started smoking? (response: } 15 \text { or } 16 \text { years } \\
\text { old) }\end{array}$ \\
\hline 17 or older & $\begin{array}{l}\text { How old were you when you smoked a whole } \\
\text { cigarette for the first time? (response: } 17 \text {-year-old } \\
\text { or older) }\end{array}$ & $\begin{array}{l}\text { Age you started smoking? (response: } 17 \text {-year-old or } \\
\text { older) }\end{array}$ \\
\hline \multicolumn{3}{|c|}{ Smoked 100 or more cigarettes } \\
\hline Yes & & $\begin{array}{l}\text { Have you smoked at least } 100 \text { cigarettes in your entire } \\
\text { life? (response: yes) }\end{array}$ \\
\hline
\end{tabular}




\begin{tabular}{|c|c|c|}
\hline Variable & Missouri Youth Tobacco Survey & Out, Proud and Healthy Survey \\
\hline & $\begin{array}{l}\text { About how many cigarettes have you smoked in } \\
\text { your entire life? (response: } 100 \text { or more } \\
\text { cigarettes) }\end{array}$ & \\
\hline No & $\begin{array}{l}\text { About how many cigarettes have you smoked in } \\
\text { your entire life? (response: none- } 99 \text { cigarettes) }\end{array}$ & $\begin{array}{l}\text { Have you smoked at least } 100 \text { cigarettes in your entire } \\
\text { life? (response: no) }\end{array}$ \\
\hline \multicolumn{3}{|c|}{ Cigarettes per day } \\
\hline $\begin{array}{l}\text { Do not } \\
\text { smoke }\end{array}$ & $\begin{array}{l}\text { During the past } 30 \text { days, on the days you smoked, } \\
\text { how many cigarettes did you smoke per day? } \\
\text { (response: I did not smoke cigarettes during the } \\
\text { past } 30 \text { days) }\end{array}$ & $\begin{array}{l}\text { On the days you smoke, how many cigarettes do you } \\
\text { smoke? (response: I did not smoke at all) }\end{array}$ \\
\hline 5 or fewer & $\begin{array}{l}\text { During the past } 30 \text { days, on the days you smoked, } \\
\text { how many cigarettes did you smoke per day? } \\
\text { (response: } 5 \text { or fewer) }\end{array}$ & $\begin{array}{l}\text { On the days you smoke, how many cigarettes do you } \\
\text { smoke? (response: } 5 \text { or fewer) }\end{array}$ \\
\hline $6-10$ & $\begin{array}{l}\text { During the past } 30 \text { days, on the days you smoked, } \\
\text { how many cigarettes did you smoke per day? } \\
\text { (response: } 6-10 \text { ) }\end{array}$ & $\begin{array}{l}\text { On the days you smoke, how many cigarettes do you } \\
\text { smoke? (response: } 6-10 \text { ) }\end{array}$ \\
\hline $11-20$ & $\begin{array}{l}\text { During the past } 30 \text { days, on the days you smoked, } \\
\text { how many cigarettes did you smoke per day? } \\
\text { (response: } 11-20 \text { ) }\end{array}$ & $\begin{array}{l}\text { On the days you smoke, how many cigarettes do you } \\
\text { smoke? (response: } 11-20 \text { ) }\end{array}$ \\
\hline $\begin{array}{l}\text { More than } \\
20\end{array}$ & $\begin{array}{l}\text { During the past } 30 \text { days, on the days you smoked, } \\
\text { how many cigarettes did you smoke per day? } \\
\text { (response: more than 20) }\end{array}$ & $\begin{array}{l}\text { On the days you smoke, how many cigarettes do you } \\
\text { smoke? (response: more than 20) }\end{array}$ \\
\hline \multicolumn{3}{|c|}{ Chewing tobacco use } \\
\hline Not at all & $\begin{array}{l}\text { During the past } 30 \text { days, on how many days did } \\
\text { you use chewing tobacco, snuff, or dip? (response: } \\
0 \text { days) }\end{array}$ & $\begin{array}{l}\text { Do you currently use chewing tobacco, snuff or snus } \\
\text { every day, some days, or not at all? (response: not at } \\
\text { all) }\end{array}$ \\
\hline Some Days & $\begin{array}{l}\text { During the past } 30 \text { days, on how many days did } \\
\text { you use chewing tobacco, snuff, or dip? (response: } \\
1-29 \text { days) }\end{array}$ & $\begin{array}{l}\text { Do you currently use chewing tobacco, snuff or snus } \\
\text { every day, some days, or not at all? (response: some } \\
\text { days) }\end{array}$ \\
\hline Every day & $\begin{array}{l}\text { During the past } 30 \text { days, on how many days did } \\
\text { you use chewing tobacco, snuff, or dip? (response: } \\
\text { all } 30 \text { days) }\end{array}$ & $\begin{array}{l}\text { Do you currently use chewing tobacco, snuff or snus } \\
\text { every day, some days, or not at all? (response: every } \\
\text { day) }\end{array}$ \\
\hline \multicolumn{3}{|l|}{ Cigar use } \\
\hline Not at all & $\begin{array}{l}\text { During the past } 30 \text { days, on how many days did } \\
\text { you smoke cigars, cigarillos, or little cigars? } \\
\text { (response: } 0 \text { days) }\end{array}$ & $\begin{array}{l}\text { Do you now smoke cigars, water pipe, bidis, kreteks, or } \\
\text { clove cigarettes every day, some days, or not at all? } \\
\text { (response: not at all) }\end{array}$ \\
\hline Some days & $\begin{array}{l}\text { During the past } 30 \text { days, on how many days did } \\
\text { you smoke cigars, cigarillos, or little cigars? } \\
\text { (response: } 1-29 \text { days) }\end{array}$ & $\begin{array}{l}\text { Do you now smoke cigars, water pipe, bidis, kreteks, or } \\
\text { clove cigarettes every day, some days, or not at all? } \\
\text { (response: some days) }\end{array}$ \\
\hline Every day & $\begin{array}{l}\text { During the past } 30 \text { days, on how many days did } \\
\text { you smoke cigars, cigarillos, or little cigars? } \\
\text { (response: all } 30 \text { days) }\end{array}$ & $\begin{array}{l}\text { Do you now smoke cigars, water pipe, bidis, kreteks, or } \\
\text { clove cigarettes every day, some days, or not at all? } \\
\text { (response: every day) }\end{array}$ \\
\hline \multicolumn{3}{|c|}{ Poly-tobacco use } \\
\hline Yes & $\begin{array}{l}\text { During the past } 30 \text { days, on how many did you } \\
\text { smoke? (response: } 1 \text { to all } 30 \text { days) } \\
\text { and } \\
\text { During the past } 30 \text { days, on how many days did } \\
\text { you use chewing tobacco, snuff, or dip? (response: } \\
1 \text { to all } 30 \text { days) } \\
\text { or } \\
\text { During the past } 30 \text { days, on how many days did } \\
\text { you smoke cigars, cigarillos, or little cigars? } \\
\text { (response: } 1 \text { to all } 30 \text { days) }\end{array}$ & $\begin{array}{l}\text { Do you NOW smoke cigarettes every day, some days or } \\
\text { not at all (response: every day or some days) } \\
\text { and } \\
\text { Do you currently use chewing tobacco, snuff or snus } \\
\text { every day, some days, or not at all? (response: every } \\
\text { day or some days) } \\
\text { or } \\
\text { Do you now smoke cigars, water pipe, bidis, kreteks, or } \\
\text { clove cigarettes every day, some days, or not at all? } \\
\text { (response: every day or some days) }\end{array}$ \\
\hline
\end{tabular}


Preventing Chronic Disease | Smoking Initiation, Tobacco Product Use, and Secondhan... Page 12 of 12

\begin{tabular}{|c|c|c|}
\hline Variable & Missouri Youth Tobacco Survey & Out, Proud and Healthy Survey \\
\hline \multicolumn{3}{|c|}{ Exposure to secondhand smoke in the home } \\
\hline $\begin{array}{l}\text { Allowed } \\
\text { some times } \\
\text { or places }\end{array}$ & $\begin{array}{l}\text { Which of these best describes the rules about } \\
\text { smoking inside the house where you live? Smoking } \\
\text { is ... (response: allowed only at some times or in } \\
\text { some places) }\end{array}$ & $\begin{array}{l}\text { Which statement best describes the rules about smoking } \\
\text { inside your home? (response: allowed in some places or } \\
\text { at some times) }\end{array}$ \\
\hline $\begin{array}{l}\text { Always } \\
\text { allowed }\end{array}$ & $\begin{array}{l}\text { Which of these best describes the rules about } \\
\text { smoking inside the house where you live? Smoking } \\
\text { is ... (response: always allowed inside my home) }\end{array}$ & $\begin{array}{l}\text { Which statement best describes the rules about smoking } \\
\text { inside your home? (response: allowed in all places inside } \\
\text { my home/there are no rules about smoking inside my } \\
\text { home) }\end{array}$ \\
\hline $\begin{array}{l}\text { Never } \\
\text { allowed }\end{array}$ & $\begin{array}{l}\text { Which of these best describes the rules about } \\
\text { smoking inside the house where you live? Smoking } \\
\text { is... (response: never allowed inside my home) }\end{array}$ & $\begin{array}{l}\text { Which statement best describes the rules about smoking } \\
\text { inside your home? (response: not allowed anywhere } \\
\text { inside my home) }\end{array}$ \\
\hline \multicolumn{3}{|c|}{ Exposure to secondhand smoke in the car } \\
\hline $\begin{array}{l}\text { Allowed } \\
\text { some times } \\
\text { or places }\end{array}$ & $\begin{array}{l}\text { Which of the following best describes the rules } \\
\text { about smoking in the vehicle you drive or ride in } \\
\text { the most? Smoking is... (response: sometimes } \\
\text { allowed inside the vehicle) }\end{array}$ & $\begin{array}{l}\text { Which statement best describes the rules about smoking } \\
\text { when you travel? (response: not allowed in my vehicle } \\
\text { but smoking can happen when I am traveling in another } \\
\text { person's vehicle/allowed sometimes, depending on the } \\
\text { person driving or the situation) }\end{array}$ \\
\hline $\begin{array}{l}\text { Always } \\
\text { allowed }\end{array}$ & $\begin{array}{l}\text { Which of the following best describes the rules } \\
\text { about smoking in the vehicle you drive or ride in } \\
\text { the most? Smoking is... (response: always allowed } \\
\text { inside the vehicle) }\end{array}$ & $\begin{array}{l}\text { Which statement best describes the rules about smoking } \\
\text { when you travel? (response: always allowed in my } \\
\text { vehicle) }\end{array}$ \\
\hline $\begin{array}{l}\text { Never } \\
\text { allowed }\end{array}$ & $\begin{array}{l}\text { Which of the following best describes the rules } \\
\text { about smoking in the vehicle you drive or ride in } \\
\text { the most? Smoking is... (response: never allowed } \\
\text { inside the vehicle) }\end{array}$ & $\begin{array}{l}\text { Which statement best describes the rules about smoking } \\
\text { when you travel? (response: not allowed in my vehicle } \\
\text { in which I travel) }\end{array}$ \\
\hline \multicolumn{3}{|c|}{ Support for smoke-free workplaces } \\
\hline Yes & $\begin{array}{l}\text { What do you think employers should do about } \\
\text { smoking in indoor areas where people work? } \\
\text { Employers should ... (response: never allow } \\
\text { smoking in places where people work) }\end{array}$ & $\begin{array}{l}\text { Do you support smoke-free policies in all indoor } \\
\text { workplaces, including bars and restaurants? (response: } \\
\text { yes) }\end{array}$ \\
\hline No & $\begin{array}{l}\text { What do you think employers should do about } \\
\text { smoking in indoor areas where people work? } \\
\text { Employers should . . . (response: allow smoking } \\
\text { only at some times or in some places/always allow } \\
\text { smoking in places where people work) }\end{array}$ & $\begin{array}{l}\text { Do you support smoke-free policies in all indoor } \\
\text { workplaces, including bars and restaurants? (response: } \\
\text { no) }\end{array}$ \\
\hline
\end{tabular}

The opinions expressed by authors contributing to this journal do not necessarily reflect the opinions of the U.S. Department of Health and Human Services, the Public Health Service, the Centers for Disease Control and Prevention, or the authors' affiliated institutions.

For Questions About This Article Contact pcdeditor@cdc.gov

Page last reviewed: July 03, 2014

Page last updated: July 03, 2014

Content source: National Center for Chronic Disease Prevention and Health Promotion

Centers for Disease Control and Prevention 1600 Clifton Rd. Atlanta, GA 30333, USA

800-CDC-INFO (800-232-4636) TTY: (888) 232-6348 - Contact CDC-INFO

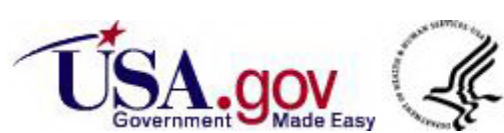

